\title{
Health Related Advertisements in Audiovisual Media: A Content Analysis in Karnataka, India
}

\author{
Manjunatha SN, Venkatesh Darshan AN, Sajja Jayashree*
}

\begin{abstract}
Introduction: Mass media provides information among people at large, so that there is acceptance of any idea to create interest. There are various types of mass media- magazines, television, internet, newspapers, etc. The media have the power to direct our attention towards certain issues. Thus it can be said that, mass media plays an important role in shaping the lifestyle and through that the habits- good or bad among the public. So, we have studied the different types of health awareness creating advertisements broadcasted in two types of mass media namely television (Audio-visual) and radio (Audio). Methods: A Content analysis of health related advertisements was done in selected channels from television and radio stations and a survey was conducted later to know the effect of those advertisements on public. Results: The major areas covered in health awareness were on DOTS, Clean drinking water, NACO-ICTC, lodized Salt and Zinc tablet. It was found that the health related advertisements especially those aimed at raising awareness decreased during weekends. In the survey conducted, it was found that not many people were interested in looking at advertisements. And of those who watched or listened to advertisements only a few could recall any health message. Conclusion: Many of the government sponsored advertisements do not find their place in commercial channels which attract larger viewership. It's better to increase health awareness related advertisements during weekends and prime time.

Key words: Audio-visual media, Health advertisements, Health awareness, Health education, Mass Media, Radio Advertisements, Television Advertisements.
\end{abstract}

\section{Manjunatha SN, Venkatesh Darshan AN, Sajja Jayashree*}

Department of Community Medicine, Mysore Medical College and Research Institute, Opposite to KR Hospital, Irwin Road, Mysore, Karnataka, INDIA

\section{Correspondence}

Dr. Sajja Jayashree,

Department of Community Medicine,

Mysore Medical College and Research Institute, Opposite KR Hospital, Irwin road, Mysore, Karnataka, INDIA.

Mobile no: +91-9686942280

Email: jaysaj2056@gmail.com

History

- Submission Date: 29-08-18

- Revised Date: 15-01-19

- Accepted Date: 28-04-19

DOI : 10.5530/ijmedph.2019.2.13

Article Available online

http://www.ijmedph.org//v9/i2

\section{Copyright}

(c) 2019 Phcog.Net. This is an openaccess article distributed under the terms of the Creative Commons Attribution 4.0 International license.

\section{INTRODUCTION}

Mass media is a mode of communication that provides information to huge number of people within limited time. There are various types of mass media which can broadly be classified into print (newspaper), audio (radio) and audio-visual (TV). The Audio visual media has higher power to direct our attention towards certain issues. ${ }^{1}$ Thus it can be said that, mass media can play an important role in shaping the lifestyle. Nowadays a large segment of the population irrespective of age, gender or socio economic status has access to mass media especially television.

Some of the leading health problems are as follows:

According to National Family Health Survey3(NFHS-3) conducted in 2005-06, the percentage of men and women aged 15-49 years smoking bidis or cigarettes in India was $32.7 \%$ and $1.4 \%$ respectively. ${ }^{2}$

Alcohol Prevalence in India among men varies from $23 \%$ to $74 \%$ and among women from $28 \%$ to $48 \%$ at different parts of India. ${ }^{3}$

PEM is measured in terms of underweight (low weight for age), stunting (low height for age) and wasting (low weight for height). The prevalence of stunting among under five is $48 \%$ and wasting is $19.8 \%$ and with an underweight prevalence of $42.5 \%$, it is the highest in the world. ${ }^{4}$
Obesity increases the risk of a number of cardiovascular problems causing significant mortality and morbidity. Overall prevalence of obesity was $6.8 \%$ (7.8 vs. $6.2 \%, P<0.05)$ and of overweight was $33.5 \%$ (35.0 vs. $32.0 \%, P<0.05)$ among women and men, respectively. ${ }^{5}$ It is proved in studies that most of the above problems can be reduced, just by increasing awareness among the population. ${ }^{6}$ Thus awareness as well as attitude and behavioral changes is required to bring about an effective change.?

Hence the study was undertaken to understand the different types of health awareness advertisements, broadcasted in two types of mass media namely television (Audio-visual) and radio (Audio). Advertisements related to products which affect health but are aimed at marketing the products were not considered.

\section{OBJECTIVES}

To study the nature, theme, timing and duration of health related advertisements broadcasted in selected channels.

To carry out content analysis of the health advertisements. 
To interview a small sample of the target population and study their recall, understanding and response patterns.

\section{MATERIALS AND METHODS}

In Mysore, there are three radio stations namely Big FM (92.7 MHz) which is owned by Anil Dhirubhai Ambani, Super hits Red FM owned by Sun group operating at $93.5 \mathrm{MHz}$ and Mysore Akashavani owned by the Government (100.6 MHz). Out of these three Big Fm (92.7 MHz) and Mysore Akashavani (100.6 MHz) were chosen by the researchers.

A list of various channels broadcasted in television commonly were categorized into kids, news, sports and movies/serials. Since it was difficult to observe multiple channels simultaneously, the researchers decided to observe only the popular channels in each category. The researchers of the study selected one most popular television channel as per their knowledge, from the following categories.

Kids channel- Pogo

News channel- TV9

Kannada channel broad casting movies and serials- Chandana Sports channel- Star Sports 1.

The advertisements in selected channels and stations were observed for a period of two months- June and July 2014. Broadcasts on health advertisement in all the above selected television and radio channels over a period of 2 months were recorded. For each commercial, following information was noted down- duration in seconds, time of broadcasting, type of product or service, disease targeted, Involvement of celebrity, sponsoring and total times of broadcasting per month. A content analysis was done later.

As the television and radio are most of the times, one-way communication modes, a survey was conducted later on outpatients in KR Hospital, to know their recalling capacity and attitude towards health related advertisements. 100 patients were selected by convenience sampling and interviewed. Men and women aged 25-50 years watching the television channels at least 4 days a week were included in the study. The common channels viewed and heard by them and routine timing of viewing and hearing was noted down.

\section{Statistical test used}

Descriptive statistics like mean and standard deviation was used.

\section{RESULTS}

\section{Radio}

Big FM

It was found that on an overage there were 90-100 health related advertisements being broadcasted per day. Out of these approximately 35-45 advertisements were on some health clinics or hospital advertisements, etc.; 10-15 were related to cosmetic and herbal products; and 15-20 were general medicine advertisements (Vicco cream, Eno etc). (Table 1) There were approximately 25-30 health awareness related advertisements which were related to DOTS, Clean drinking water and hygiene around house and about birth and death registration on weekdays and on weekends frequency reduced to 5-10 advertisements per day. (Table 1)

Among the health awareness related advertisements, awareness about DOTS, birth and death registration was given maximum importance followed by awareness on clean drinking water and personal hygiene. One special thing observed was heath awareness related advertisements reduced during weekends with no advertisements on DOTS and clean drinking water practices and a very few on birth and death registration of 5-10 per day. Further details of the common advertisements are given in Table 2.

\section{Mysore Akashavani}

It was found that on an average there was 130-140 health related advertisements being broadcasted per day. Out of these 15-20 were related to cosmetic and herbal products (Vicco cream, Eno etc.). There were approximately 100-120 health awareness related advertisements. Health awareness related advertisements reduced during weekends to almost nil or very few. (Table 1 )

\begin{tabular}{|c|c|c|c|c|c|c|c|}
\hline Channel & Day & Hospitals & Cosmetics & $\begin{array}{l}\text { General } \\
\text { medicines }\end{array}$ & $\begin{array}{l}\text { Health } \\
\text { drinks }\end{array}$ & $\begin{array}{l}\text { Baby } \\
\text { products }\end{array}$ & $\begin{array}{c}\text { Health } \\
\text { awareness }\end{array}$ \\
\hline \multirow{2}{*}{ BIG FM } & Weekday & $35-45$ & $10-15$ & $15-20$ & - & - & $25-30$ \\
\hline & Weekend & $35-45$ & $10-15$ & $20-25$ & - & - & $5-10$ \\
\hline \multirow{2}{*}{ Mysore Akashvani } & Weekday & - & $15-20$ & - & - & - & $100-120$ \\
\hline & Weekend & - & $15-20$ & - & - & - & $20-30$ \\
\hline \multirow{2}{*}{ DD Chandana } & Weekday & - & $15-20$ & - & - & - & $8-10$ \\
\hline & Weekend & - & $2-5$ & - & - & - & 0 \\
\hline \multirow{2}{*}{ TV9 } & Weekday & $15-20$ & $25-30$ & $15-20$ & - & - & $50-60$ \\
\hline & Weekend & $15-20$ & $25-30$ & $15-20$ & - & - & $5-10$ \\
\hline \multirow[t]{2}{*}{ Pogo } & Weekday & - & $10-15$ & - & $50-55$ & $20-25$ & 0 \\
\hline & Weekend & - & $10-15$ & - & $50-55$ & $20-25$ & 0 \\
\hline \multirow{2}{*}{ Star sports } & Weekday & - & $15-20$ & $10-15$ & $40-45$ & - & 0 \\
\hline & Weekend & - & $15-20$ & $10-15$ & $40-45$ & - & 0 \\
\hline
\end{tabular}




\begin{tabular}{|c|c|c|c|c|c|c|}
\hline $\begin{array}{c}\text { Details of } \\
\text { advertisements }\end{array}$ & DOTS & $\begin{array}{l}\text { Clean drinking } \\
\text { water }\end{array}$ & $\begin{array}{l}\text { Birth and death } \\
\text { registration }\end{array}$ & NACO/ICTC & lodised salt & Zinc tablet \\
\hline Channel & Both & Both & Both & $\begin{array}{c}\text { Mysore } \\
\text { Akashvani }\end{array}$ & $\begin{array}{c}\text { Mysore } \\
\text { Akashvani }\end{array}$ & $\begin{array}{c}\text { Mysore } \\
\text { Akashvani }\end{array}$ \\
\hline Duration in sec & 30 & 38 & 30 & 60 & 40 & 30 \\
\hline \multicolumn{7}{|l|}{ Broadcast time $^{\star}$} \\
\hline $8 a m-12 p m$ & $3-6$ & $1-6$ & $3-5$ & $5-6$ & $5-6$ & $5-6$ \\
\hline $12 p m-6 p m$ & $5-10$ & $2-10$ & $5-6$ & $8-10$ & $8-10$ & $8-10$ \\
\hline $6 p m-11 p m$ & $2-5$ & $1-5$ & $2-3$ & $4-5$ & $4-5$ & $4-5$ \\
\hline Type of product & Free drugs & Hygiene awareness & $\begin{array}{c}\text { Free } \\
\text { registration }\end{array}$ & Free drugs & $\begin{array}{l}\text { Use of iodised } \\
\text { salt }\end{array}$ & Free tablets \\
\hline Disease targeted & ТВ & $\begin{array}{l}\text { Malaria Typhoid } \\
\text { Cholera }\end{array}$ & - & HIV/AIDS & Goiter & Diarrhea \\
\hline $\begin{array}{l}\text { Celebrity } \\
\text { involvement }\end{array}$ & No & Neha Dhupia & No & No & No & No \\
\hline Sponsoring & MoHFW & $\begin{array}{l}\text { Ministry of drinking } \\
\text { water and cleanliness }\end{array}$ & $\begin{array}{l}\text { Registrar general } \\
\text { of India }\end{array}$ & MoHFW & MoHFW & MoHFW \\
\hline $\begin{array}{c}\text { Total times } \\
\text { broadcasted/ } \\
\text { month }^{*}\end{array}$ & $350-650$ & $150-650$ & $350-450$ & $600-650$ & $600-650$ & $600-650$ \\
\hline
\end{tabular}

\begin{tabular}{|c|c|c|c|c|c|c|c|c|}
\hline Details of ads & $\begin{array}{l}\text { Iron } \\
\text { and } \\
\text { folic } \\
\text { acid }\end{array}$ & Vaccine & $\begin{array}{c}\text { Anti- } \\
\text { smoking }\end{array}$ & $\begin{array}{l}\text { Clean } \\
\text { drinking } \\
\text { water }\end{array}$ & $\begin{array}{l}\text { Birth and } \\
\text { death } \\
\text { registration }\end{array}$ & NACO/ICTC & lifestyle & Medicine \\
\hline Channel & DD & DD & DD & TV9 & TV9 & TV9 & TV9 & TV9 \\
\hline $\begin{array}{l}\text { Duration in } \\
\text { seconds }\end{array}$ & 40 & 40 & 40 & 38 & 30 & 60 & 40 & 30 \\
\hline \multicolumn{9}{|l|}{ Broadcasting time } \\
\hline $8 \mathrm{am}-12 \mathrm{pm}$ & 0 & 0 & 0 & $2-3$ & $2-3$ & $1-2$ & $4-6$ & 0 \\
\hline $12 \mathrm{pm}-6 \mathrm{pm}$ & 0 & 0 & 0 & $4-6$ & $4-6$ & $5-6$ & $6-8$ & $3-5$ \\
\hline $6 \mathrm{pm}-11 \mathrm{pm}$ & $2-3$ & $2-3$ & $2-3$ & $2-3$ & $2-3$ & $2-3$ & $4-6$ & $1-2$ \\
\hline Type of product & $\begin{array}{l}\text { Free } \\
\text { drug }\end{array}$ & $\begin{array}{c}\text { Free } \\
\text { vaccine }\end{array}$ & $\begin{array}{l}\text { Adverse ef- } \\
\text { fects }\end{array}$ & $\begin{array}{l}\text { Hygiene } \\
\text { awareness }\end{array}$ & Free reg. & Free drugs & $\begin{array}{c}\text { Vegetable } \\
\text { Consumption }\end{array}$ & Expiry date \\
\hline \multirow{3}{*}{ Disease targeted } & \multirow{3}{*}{$\begin{array}{l}\text { Iron def. } \\
\text { anaemia }\end{array}$} & Tetanus & & Malaria & & & & \\
\hline & & $\begin{array}{l}\text { Whooping } \\
\text { cough }\end{array}$ & \multirow[t]{2}{*}{$\begin{array}{l}\text { All tobacco } \\
\text { diseases }\end{array}$} & $\begin{array}{l}\text { Cholera } \\
\text { Typhoid }\end{array}$ & \multirow[t]{2}{*}{ 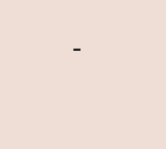 } & \multirow[t]{2}{*}{ HIV/ AIDS } & Obesity & \multirow[t]{2}{*}{ - } \\
\hline & & Hepatitis B & & & & & & \\
\hline $\begin{array}{c}\text { Celebrity involve- } \\
\text { ment }\end{array}$ & - & - & - & Neha Dhupia & - & - & - & - \\
\hline $\begin{array}{l}\text { Total times broad- } \\
\text { casted/ month }\end{array}$ & $60-70$ & $60-70$ & $60-70$ & $300-350$ & $300-350$ & $250-300$ & $500-550$ & $150-200$ \\
\hline
\end{tabular}


It was observed that almost all health awareness related advertisements were given equal importance. (Table 2) There was a talk show broadcasted every Saturday and Sunday from 11.00-11.15 am in which the various aspects of cleanliness and personal hygiene and its effect on life was discussed. It was sponsored by Department of Health and Family Welfare, Central government of India under the NRHM programme.

\section{Television}

\section{Entertainment channel: DD Chandana}

It was found that there were very few advertisements in this channel overall. There were approximately 25-30 health related advertisements being broadcasted per day. Out of these approximately 15-20 were cosmetic products. (Table 1 ) There were approximately $8-10$ health awareness related advertisements which were related to iron supplementation, vaccination for infants and adverse effects of smoking. (Table 3)

There was one phone-in programme in which a doctor was called and he/she gave advice and solved health related queries of people who called for help. It was broadcasted from 6.00-6.30 pm on all weekdays. The different issues dealt were normally related to AIDS, immunisation of children different types of cancer, oral health, infections (viral, bacterial and fungal), eyes, injuries, respiratory problems, gynecological problems, joint pains, neurological problems, lifestyle diseases (diabetes, hypertension), cardiac problems, different types of allergies and aches, etc. There was also a talk by food experts on healthy food for 5 mins every day between 3.00-3.30 pm. There were no health awareness related advertisements during weekends except for one advertisement on reducing our carbon footprints which was indirectly related to health by raising awareness on pollution.

\section{TV9 Kannada - News channel}

There were approximately 180-200 health related advertisements being broadcasted per day. There was preponderance of advertisements as there were approximately 25-30 advertisements of cosmetics; 15-20 were on Hospitals and health clinics; 15-20 were general medicines advertisements (Crocin, Otrivin, Cough-Syrup, etc.); approximately 8-10 were related to ayurvedic products like Dabur products and Chawanprash and 50-60 health awareness related advertisements.

From Table 3, it can be observed that advertisement on vegetable consumption was given maximum emphasis (500-550) whereas that on expiry date of medicines was given the least importance (150-200). There were approximately 50-60 health awareness related advertisements being broadcasted per day which were related to clean drinking water, NACO, uses of vegetable consumption etc., the details of which are as given in the table below. There were very few advertisements regarding health awareness during weekends.

\section{Pogo and Star Sports}

There were no health awareness related advertisements in these two channels. Additionally there were abundant advertisements on health drinks in both the channels and baby products, oral hygeine in pogo. (Table 1)

\section{Survey}

Out of the 100 people surveyed 64 were males and 36 females. Mean age of the population was 32.75 years ( $\mathrm{SD}=7.98$ years). Among the mass media studied, average duration of listening to radio was the highest- 2.24 hrs followed by watching television $-1.68 \mathrm{hrs}$.

Out of the 100 people, 57 people told that they paid attention to advertisements, whereas the rest 43 told that they either switch channels during advertisements or just do not pay attention to the advertisements.
Out of 57, 21 people who could recall health awareness related advertisements, 11 (53.38\%) people told that they could recall it from radio, 8 (38.09\%) from television. Recall was better for the advertisements involving celebrities. Thus radio was the most effective mass media in influencing the recall of health awareness.

\section{DISCUSSION}

It was found that there was a significant increase in all the types of health related advertisements in Big FM in our present study compared to the study done by Gupta A, Sinha $\mathrm{AK}^{1}$ which was also done on Big FM in 2010. This may have been due to the increase in the fame of Big FM during the last four years with consequent increase in the number of advertisements. The good thing is that health awareness related advertisements have also increased to the same extent.

It was found that Mysore Akashavani which is owned by the government broadcasts the maximum number of health advertisements (130-140) of which 115-120 were directly related to health awareness. This shows that Government is working towards raising awareness on health issues among the general public.

It was found in our present study that there were very few health related advertisements in government owned DD Chandana i.e., 25-30 of which only 8-10 were health awareness related. In the other study there was 120-130 health related advertisements of which beauty product ranked first with 35-40 advertisements, contraceptives ranked last with 2-5 and Health awareness related advertisements were just 7-9. This shows the lack of commitment among both Doordarshan and private entertainment channels to raise awareness about health issues. ${ }^{1}$

There were far more health related advertisements in our study of TV9 Kannada (130-140) than the other study of IBN7 (35-40). Of these, health awareness related advertisements were the highest (50-60) in our study. In the other study ${ }^{1}$ advertisements on cosmetic products were the highest (14-16) and health awareness related advertisements were very few i.e., 9-14.

According to a study by Neeta Ghimire and Arathi Rao, ${ }^{8}$ out of 281 advertisements on children's favorite channels, 162 were for food products (of which 142 were for calorigenic food), 26.69\% were for nonfood products (stationary items, toys) and $8.54 \%(n=24)$ were for other health-related products. Among $98.8 \%$ of the children, $74.2 \%$ watched the advertisements between programs and $25.8 \%$ did not watch them. Of the children, $75 \%$ were highly influenced by the advertisements and asked their parents to buy advertised products; $66 \%$ of the children asked for food and $48.50 \%$ asked for soft drinks. According to a study by Sukumaran A, Diwakar MP, Shastry $\mathrm{SM}^{9}$ it was found that the advertisement of sugar-rich food products, non-food and oral hygiene products occupied $50.36 \%, 38.41 \%$ and $1.90 \%$, respectively, of the total advertising time. Solid and sticky products made up $100 \%$ of advertisements in this category on Chithiram television channel, compared with $62.5 \%$ of advertisements on Chutti television channel. In our study it was found that there were 120-130 health advertisements per day of which those related to health drinks such as horlicks, boost etc, were the highest 50-55 followed by oral health products such as toothpaste, brush etc. There were absolutely no health awareness related advertisements in the channel.

Thus it was found that both in the present study and the other two studies, food items formed the major chunk, accounting for $50 \%$ of advertisements in kid's channel. This commercialization of children's television programs is one of the several concerns raised by child health professionals, regarding the impact of television on children's well being. ${ }^{10}$ According to the study by Neeta Ghimire and Arathi Rao, ${ }^{8} 75 \%$ of the children are highly influenced by the advertisements with respect to eating habits. So, there is a need to educate children about the advertisements they 
see and also about healthy food practices so that they do not fall prey to obesity and other complications. In our present study the influence of such advertisements on children could not be assessed as our study group consisted of 20-50 years old people.

It was found that approximately 90-100 health related advertisements were broadcasted per day, of which those related to health drinks like Horlicks, boost etc., were the highest with absolutely no health awareness related advertisements. This might probably because the advertisement slots in this channel are quite expensive and the government can't sponsor it.

\section{Survey}

We interviewed 100 randomly selected outpatients attending KR Hospital. They were interviewed on the number of hours spent on different mass media - radio, television; their recall of any health awareness related advertisements from any mass media; and its influence on their lives. It is suggested that more and more celebrities must be involved in health awareness related advertisements so that the advertisements are more effective. According to a study by Pepper JK ${ }^{6}$ et.al in USA, 2012 - $60 \%$ of the people believed that a logo-free vaccine related advertisement was sponsored by a drug company and was associated with lack of trust. Therefore more government sponsored advertisements must be encouraged.

\section{The Future}

Since ages, media has been known to be one of the most powerful mode of communication. Even then health sector has failed to utilize this effectively. One of the most important reasons for this might be due to the costs involved. Studies in this area are relatively less till today. Therefore similar studies in the future might help us to know the trends and utilize the mass media effectively for the promotion, prevention and maintenance of the health among people.

\section{CONCLUSION}

Recall is better if the health related advertisements contained celebrity. The frequency of health awareness related advertisements during weekends and prime time was less.

The advertisements related to junk food and health drinks were broadcasted on KIDS channels.

\section{RECOMMENDATIONS}

- Messages of public health importance should be delivered by involving celebrities as ambassadors for the same.

- Health related advertisements should be broadcasted more on weekends and prime time to increase chances of reaching out the message to more audience.

- Advertisements related to hospitals, health drinks and drugs should be regulated.

- $\quad$ Advertisements related to junk food and health drinks especially in the kids channel must be regulated.

\section{CONFLICT OF INTEREST}

The authors declare that there is no conflict of interest.

\section{ABBREVIATIONS}

None

\section{REFERENCES}

1. Gupta A, Sinha A. Health Coverage in Mass Media: A Content Analysis. Journal of Communication. 2010;1(1):19-25

2. Kumar SR, Swaminathan S, Flanigan T, Mayer K, Niaura R. HIV and smoking in India. Indian J Med Res. 2009;130(1):15-22.

3. http://apapaonline.org/data/National_Data/India/Alcohol_Consumption_India. pdf.

4. Bhutia DT. Protein Energy Malnutrition in India: The Plight of Our Under Five Children. J Family Med Prim Care. 2014;3(1):63-7.

5. Kalra S, Garg M, Unnikrishnan A. Preventing obesity in India: Weighing the options. Indian Journal of Endocrinology and Metabolism. 2012;16(1):4

6. Kaur J, Kishore J, Kumar M. Effect of Anti-Tobacco Audiovisual Messages on Knowledge and Attitude towards Tobacco Use in North India. Indian J Community Med. 2012;37(4):227-31

7. Wakefield M, Szczypka G, Terry-McElrath Y, Emery S, Flay B, Chaloupka F, et al. Mixed messages on tobacco: comparative exposure to public health, tobacco company- and pharmaceutical company- sponsored tobacco- related television campaigns in the united states. 2013;22 (e1):e57-65. Epub 2012 Jun 29.

8. Stacks DW, Hocking JE. Essentials of communication research. New York. NY: HarperCollins. 1992;250.

9. Boles M, Adams A, Gredler A, Manhas S. Ability of a mass media campaign to influence knowledge, attitudes and behaviors about sugary drinks and obesity. Preventive Medicine. 2014;67:S40-5.

10. Ghimire N, Rao A. Comparative evaluation of influence of television advertisements on children and caries prevalence. Global Health Action. 2013;6(1):1-19.

Cite this article : Manjunatha SN, Darshan AN, Jayashree $S^{*}$. Health Related Advertisements in Audiovisual Media: A Content Analysis in Karnataka, India. Int J Med Public Health. 2019;9(2):50-4.. 